\title{
Nitrogen use efficiency in forage yield of tropical maize populations
}

\section{Eficiência e uso de nitrogênio na produção de forragem em populações tropicais de milho}

\author{
Leandro Lopes Cancellier ${ }^{1 *}$; Renzo Garcia Von Pinho²; Eduardo Lopes Cancellier \\ Luiz Paulo Miranda Pires ${ }^{1}$; Flávio Sérgio Afférri ${ }^{4}$; Joênes Mucci Peluzio ${ }^{5}$
}

\begin{abstract}
The development of adapted cultivars to nitrogen stress conditions is shown as an ecologically sustainable option to ensure higher yields in low input agricultural systems. This study aimed to evaluate the NUE in tropical maize (Zea mays L.) populations to forage production in the south of the State of Tocantins. Two experiments were done corresponding to low and high $\mathrm{N}$ availability sown on November 21, 2009. Twenty four maize populations and a commercial cultivar BR 106 were used in the experiments. The experimental design was a randomized block with two replicates. Plant height, ear height, ear participation in plant total green mass, ear green mass; plant green mass without ear, total green mass and NUE in forage production were evaluated. Through Moll methodology differences among populations for nitrogen use efficiency were found, however these differences weren't found on Fischer methodology. Populations 12-4, 1-3, 12-6, 12-5, 26-1, 15-2, 25-2 and 1-5 are considered efficient in nitrogen use. The populations $12-6,12-5,12-4,1-3,1-4,1-5$ and 15-2 are the best populations to use in high and low $\mathrm{N}$ environment, combining great production of green mass and being efficient in $\mathrm{N}$ use.
\end{abstract}

Key words: Zea mays, genetic breeding, silage, abiotic stress

\section{Resumo}

$\mathrm{O}$ desenvolvimento de cultivares adaptadas à estresse de nitrogênio $(\mathrm{N})$ é uma das opções de sustentabilidade ecológica para aumentar a produtividade em sistemas agrícolas de baixa e também alta tecnologia. O objetivo com este trabalho foi avaliar a eficiência e uso de $\mathrm{N}$ (EUN) em populações tropicais de milho (Zea mays L. ) para a produção forrageira no Sul do Estado do Tocantins. Dois experimentos foram instalados em novembro de 2009, um com baixa disponibilidade de $\mathrm{N}$ e outro com alta disponibilidade de $\mathrm{N}$. Vinte e quatro populações e uma cultivar comercial foram usadas nos experimentos. O delineamento experimental utilizado foi blocos casualizados com duas repetições. Foram avaliadas a altura de plantas e espiga, a participação da espiga na massa total da planta, massa verde da planta com e sem espiga, massa verde total e EUN na produção de forragem. Pelo método de Moll, foram observadas diferenças entre populações para a EUN, porém essas diferenças não foram observadas pela metodologia de Fischer. As populações 12-4, 1-3, 12-6, 12-5, 26-1, 15-2, 25-2 e 1-5 são consideradas eficientes no uso de $\mathrm{N}$. As populações 12-6, 12-5, 12-4, 1-3, 1-4, 1-5 e 15-2 são as melhores para uso em ambientes de alto e baixo $\mathrm{N}$, combinando uma satisfatória produção de massa verde e sendo eficiente no uso de $\mathrm{N}$.

Palavras-chave: Zea mays, melhoramento genético, silagem, estresse abiótico

1 Eng $^{\mathrm{os}_{\mathrm{S}}} \mathrm{Agr}^{\mathrm{os}_{\mathrm{s}}}$, Discentes do Curso de Doutorado em Fitotecnia, Dept ${ }^{\mathrm{o}}$ de Agricultura Universidade Federal de Lavras, UFLA, Lavras, MG, Brasil. E-mail: leandrocancellier@gmail.com; luizpaulo_vortex@hotmail.com

2 Eng ${ }^{\circ}$ Agr $^{\circ}$, Prof. Dr. da UFLA, Lavras, MG. Brasil. E-mail: renzo@dag.ufla.br

3 Eng $^{\mathrm{o}}$ Agr $^{\mathrm{o}}$, Discente do Curso de Doutorado em Ciência do Solo, Dept ${ }^{\circ}$ de Ciência do Solo, UFLA, Lavras, MG, Brasil. E-mail: educancellier@gmail.com

4 Eng ${ }^{\circ}$ Agr $^{\circ}$, Prof. Dr. da Universidade Federal de São Carlos, Campus Lagoa do Sino, UFSCar, Buri, SP, Brasil. E-mail: flavioafferri@gmail.com

5 Eng $^{\mathrm{O}}$ Agr $^{\circ}$, Prof. Dr. da Universidade Federal do Tocantins, UFT, Campus de Palmas, TO, Brasil. E-mail: joenesp@uft.edu.br Author for correspondence 


\section{Introduction}

In Brazil, a large part of maize production is performed by small and medium-sized farmers with some type of environmental stress that leads to low yield. In the Brazilian northern region, high temperatures, farmer's low technology and mainly lack of adapted varieties to abiotic stress conditions are causes of low grain and forage yield in the region (CANCELLIER et al., 2011; CARVALHO; SOUZA, 2007).

The big $\mathrm{N}$ fertilizer cost and the farmers' small purchasing power justifies efforts to develop cultivars with higher capacity to utilize these resources (SOARES et al., 2011) or populations that may be sources of tolerance genes to the imposed stress. The rational use of $\mathrm{N}$ fertilizer is fundamental to increase crop yield and reduce production costs (FAGERIA; SANTOS; CUTRIM, 2007; PISSINATI et al., 2013). High $\mathrm{N}$ use efficiency genotypes are desirable in low input agriculture and in higher input situations. This is because the waste and lack of this mineral element that is the most required by plants may generate economic and environmental problems as well as public health and food security (ROESCH et al., 2005).

The $\mathrm{N}$ has influence over rates of the emergence, expansion and leaf area duration, so it acts in the interception of photosynthetically active radiation as well as in its efficient use. $\mathrm{N}$ also affects the photosynthetic rate and dry biomass yield, it's an important characteristic when concerning maize silage production. Conditions of $\mathrm{N}$ deficiency in plants result in lower production of chlorophylls and proteins, in which results in lower photoasssimilate production and thus in lower green matter conversion. In this sense genotypes with high $\mathrm{N}$ use efficiency (NUE) have greater capacity to assimilate $\mathrm{CO}_{2}$ and synthesize carbohydrates in the photosynthesis, resulting in a higher dry biomass accumulation and higher grain yield according to Jakelaitis, Silva and Ferreira (2005).
The development of adapted cultivars to $\mathrm{N}$ stress conditions is presented as an ecologically sustainable option to ensure higher yields in low input agricultural systems and it has been sought by many researchers (CANCELLIER et al., 2011; MONNEVEUX; ZAID; SANCHES, 2005; PRESTERL et al., 2002; SOUZA et al., 2008). The selection of high nitrogen use efficiency genotypes in breeding programs are taken as one of the most appropriate manners to decrease production costs of many crops (MAJEROWICZ et al., 2002).

According to Coimbra et al. (2010), maize populations are yielding less than modern cultivars, despite showing a complex genetic structure, being an important source of variability when seeking tolerance genes to biotic and abiotic factors. There are reports in the literature of efficient maize populations in N stress conditions (MAJEROWICZ et al., 2002; MÉDICI et al., 2004; PRESTERL et al., 2002; SOARES et al. 2011; SOUZA et al., 2008), proving that maize populations have enough genetic variability to succeed in breeding programs of low $\mathrm{N}$ availability, however in these works focus is on the grain yield and works that considers the effect of nitrogen use efficiency on forage production, the main characteristic of maize silage production aren't found.

In addition to a decrease in the production cost, the obtainment of efficient populations in $\mathrm{N}$ use may lead to a better soil coverage due to greater forage yield, therefore the aim of this work was to evaluate nitrogen use efficiency in UFT tropical maize population concerning the forage production in south of the Tocantins State.

\section{Materials and Methods}

Were used twenty-four open pollinated populations and one commercial population (BR 106) as the control. The open pollinated populations are belong to Federal University of Tocantins (UFT) maize breeding program and the commercial 
population BR 106 belongs to Brazilian Agricultural Research Company (EMBRAPA). The populations, except BR 106, were formed by open pollination of inbred lines groups in isolated fields for four generations. The criterion to choose line groups was done by characteristics like kernel color, leaves and cob sanity, stay green, grain yield, green mass production, plant height, precocity and origin. The inbred lines were obtained from $\mathrm{F}_{2}$ generation by commercial hybrids using a pedigree method.

Two adjacent trials were done, each one corresponding to one level of $\mathrm{N}$ fertilization as topdressing, one trial at low $\mathrm{N}$ level, corresponding to $0 \mathrm{~kg} \mathrm{ha}^{-1}$ of $\mathrm{N}$ on top-dressing and another trial with high $\mathrm{N}$ level, corresponding to $150 \mathrm{~kg} \mathrm{ha}^{-1}$ of $\mathrm{N}$ on top-dressing using urea as $\mathrm{N}$ source, sown in the experimental area of Federal University of Tocantins State at Gurupi-TO, on November 21, 2009 , was located at $11^{\circ} 4442$ south latitude and 4903'02" west longitude.

The experimental design used in both trials was randomized blocks with two replicates. In the trial field the conventional tillage system was utilized and plots were composed by four rows of four meters long with rows spacing of 0.9 meters and the two central rows were considered for evaluation.

The sowing fertilization was performed using $600 \mathrm{~kg} \mathrm{ha}^{-1}$ of formulated fertilizer 4-14-8, corresponding to NPK levels in the same way on both trials ( $\mathrm{N}$ levels), totalizing $24 \mathrm{~kg} \mathrm{ha}^{-1}$ of $\mathrm{N}$ in low $\mathrm{N}$ level and $174 \mathrm{~kg} \mathrm{ha}^{-1}$ of $\mathrm{N}$ in high $\mathrm{N}$ level (24 kg ha-1 in sowing and $150 \mathrm{~kg} \mathrm{ha}^{-1}$ of $\mathrm{N}$ in top dressing). The maize was sown in order to obtain 60 thousand plants $\mathrm{ha}^{-1}$. The high $\mathrm{N}$ trial fertilization was done at the stage of four completely developed leaves. Cultural treatments to control weed, pests and diseases control were performed according to crop technical recommendations.

The following characteristics were evaluated: Plant and ear height were recorded on 10 competitive plants per plot, and measured as the distance from the soil surface to the node of the flag leaf and to the highest ear bearing node, respectively. Ear participation in total green mass of the plant was done by ratio of ear green mass by total green mass of plants. The ear green mass was a measurement weighted the ears of two central rows when the plants was in farinaceous (R5) stage and values showed in $\mathrm{kg} \mathrm{ha}{ }^{-1}$. Plant green mass without ear was obtained by weighted plants of two central rows removed the weight of the green mass of the ears belonging to two central rows when plants was in farinaceous (R5) stage. Total green mass was evaluated by weighted plants belonging to two central rows of the plot when plants were in farinaceous (R5) stage.

The NUE was evaluated from the total green mass yield NUE according to the method of Fischer, Johnson and Edmeades (1983) using the equation 1:

$$
N U E=\left[\mathrm{Y}_{\mathrm{a}}(-\mathrm{N}) / \mathrm{Y}_{\mathrm{a}}(+\mathrm{N})\right]+\left[\mathrm{Y}_{\mathrm{x}}(-\mathrm{N}) / \mathrm{Y}_{\mathrm{x}}(+\mathrm{N})\right]
$$

where $\mathrm{Y}_{\mathrm{a}}(-\mathrm{N})$ is the population "a" yield in low $\mathrm{N} ; \mathrm{Y}_{\mathrm{a}}(+\mathrm{N})$ is the population "a" yield in high $\mathrm{N} ; \mathrm{Y}_{\mathbf{x}}(-\mathrm{N})$ is the average yield of all populations in low $\mathrm{N}$ and $\mathrm{Y}_{\mathrm{x}}(+\mathrm{N})$ is the average yield of all populations in high $\mathrm{N}$.

The NUE was also evaluated also through the method of Moll, Kamprath and Jackson (1982) using the equation 2 :

$$
\mathrm{NUE}=\mathrm{G}_{\mathrm{w}} / \mathrm{N}_{\mathrm{s}}
$$

where $G_{w}$ is the grain weight, and $\mathbf{N}_{\mathbf{s}}$ is the mass of $\mathrm{N}$ applied to the soil.

After all data were collected, a combined analysis of variance was done according to the statistical model below:

$$
Y_{i j k}=\mu+P_{i}+N_{k}+B_{j(k)}+P_{i k}+\varepsilon_{i j k}
$$

where: $\mu$ is the general mean; $\mathbf{P}_{\mathbf{i}}$ is the effects of 
$\mathrm{i}^{\text {th }}$ population; $\mathbf{N}_{\mathbf{k}}$ is the effects of $\mathrm{k}^{\text {th }}$ nitrogen level; $\mathbf{B}_{j(\mathrm{k})}$ is the effect of $\mathrm{j}^{\text {th }}$ block in $\mathrm{k}^{\text {th }}$ nitrogen level; $\mathrm{PN}_{\mathrm{ik}}$ is the interaction between nitrogen level and population and $\varepsilon_{i j k}$ is the error associated with each plot. The population, nitrogen levels and interaction effects were assumed as fixed effects and block and error were assumed as random effects.

Afterwards the Scott-Knott grouping test at 5\% significance level was applied to populations and nitrogen levels, when significant differences occurred by the F test.

\section{Results and Discussion}

In general, there were a good precision on the experiment evaluation. It can be seen by low coefficient of variation (Table 1). There are significant differences among all characteristics with exception ear participation and NUE by Fischer for genotype and $\mathrm{N}$ availability. There aren't genotype by environment interaction for all characteristics, but was realized the split of the interaction to observe the combined effects. Despite the absence of significant interaction, the split of the interaction showed different response.

Table 1. Analysis of variance of total green mass (TGM) in $\mathrm{kg} \mathrm{ha}^{-1}$, ear participation in plant green (EP) mass in \%, plant green mas without ear (PGM) in $\mathrm{kg} \mathrm{ha}^{-1}$, ear green mass (EGM) in $\mathrm{kg} \mathrm{ha}^{-1}$, ear height (EH) in $\mathrm{cm}$ and plant height $(\mathrm{PH})$ in $\mathrm{cm}$, nitrogen use efficiency by Moll methodology (Moll) and nitrogen use efficiency by Fischer methodology (Fischer) of 25 maize populations in High and Low N at Gurupi-TO, crop season 2009/2010.

\begin{tabular}{|c|c|c|c|c|c|c|c|c|c|}
\hline \multirow{2}{*}{ SV } & \multirow{2}{*}{$\mathrm{DF}$} & \multicolumn{8}{|c|}{ Mean Square } \\
\hline & & TGM & EP & EGM & PGM & $\mathrm{EH}$ & $\mathrm{PH}$ & Moll & Fischer \\
\hline Pop & 24 & $125452189 * *$ & 31.24 & $14548477 * *$ & $67053466 * *$ & $433 * *$ & $843 * *$ & $50879 *$ & 0.022 \\
\hline $\mathrm{N}$ & 1 & $4659441250 * *$ & 60.37 & $516648354 * *$ & $2196009550 * *$ & $8987 * *$ & $22650 * *$ & $29241056 * *$ & - \\
\hline $\mathrm{N}^{*}$ Pop & 24 & 22584653 & 20.40 & 3257346 & 10048182 & 59.4 & 232.3 & 26213 & - \\
\hline $\operatorname{Rep}(N)$ & 2 & 168959106 & 57.75 & 11637463 & 76361420 & 60.8 & 464.2 & 160041 & 0.01 \\
\hline Error & 48 & 41211297 & 21.81 & 5113896 & 22092376 & 108.1 & 225.3 & 29294 & 0.055 \\
\hline C.V. & & 16.4 & 12.3 & 15.2 & 19.5 & 9.9 & 7.7 & 21.3 & 22.9 \\
\hline
\end{tabular}

* and **, significative by $\mathrm{F}$ test at 5 and $1 \%$ of probability. For EUN by Fischer, analysis of variance only for genotype, DF of Rep $=1$ and Error=24.

Source: Elaboration of the authors.

Concerning ear height, the populations were sorted into two groups in high $\mathrm{N}$ (Table 2). The group of greater averages in the ear height has averages varying from 136.0 to $120.5 \mathrm{~cm}$, with seven populations, and one group of smaller averages with 18 populations and averages varying from 91.0 to $117.0 \mathrm{~cm}$. In low $\mathrm{N}$, seven populations are in the group of greater averages of the ear height, with values ranging from 118.0 to $102.0 \mathrm{~cm}$ and 18 populations in the group of smaller averages of the ear height. Populations 15-2, 10-1, 12-4 and PO composed the group of greater ear height averages in high and low $\mathrm{N}$. 
Table 2. Average values of ear height $(\mathrm{cm})$ and plant height $(\mathrm{cm})$ of 25 maize populations in High and Low $\mathrm{N}$ at Gurupi-TO, crop season 2009/2010.

\begin{tabular}{|c|c|c|c|c|c|c|}
\hline \multirow{2}{*}{ Population } & \multicolumn{3}{|c|}{ Ear height } & \multicolumn{3}{|c|}{ Plant height } \\
\hline & High N & Low N & Mean & High $\mathrm{N}$ & Low N & Mean \\
\hline $15-2$ & $127.0 \mathrm{aA}$ & $118.0 \mathrm{aA}$ & $122.5 \mathrm{a}$ & $240.0 \mathrm{aA}$ & $208.0 \mathrm{aA}$ & $224.0 \mathrm{a}$ \\
\hline $12-5$ & $117.0 \mathrm{bA}$ & $109.5 \mathrm{aA}$ & $113.2 \mathrm{a}$ & $215.0 \mathrm{aA}$ & $216.5 \mathrm{aA}$ & $215.7 \mathrm{a}$ \\
\hline $10-1$ & $136.0 \mathrm{aA}$ & $116.0 \mathrm{aA}$ & $126.0 \mathrm{a}$ & $234.0 \mathrm{aA}$ & $197.0 \mathrm{aB}$ & $215.5 \mathrm{a}$ \\
\hline $12-4$ & $132.0 \mathrm{aA}$ & $112.5 \mathrm{aA}$ & $122.2 \mathrm{a}$ & $219.0 \mathrm{aA}$ & $203.0 \mathrm{aA}$ & $211.0 \mathrm{a}$ \\
\hline $1-3$ & $114.5 \mathrm{bA}$ & $102.0 \mathrm{aA}$ & $108.2 \mathrm{a}$ & $222.5 \mathrm{aA}$ & $197.5 \mathrm{aA}$ & $210.0 \mathrm{a}$ \\
\hline $12-6$ & $134.0 \mathrm{aA}$ & $96.0 \mathrm{bB}$ & $115.0 \mathrm{a}$ & $228.0 \mathrm{aA}$ & $188.0 \mathrm{aB}$ & $208.0 \mathrm{a}$ \\
\hline $25-5$ & $104.5 \mathrm{bA}$ & $90.0 \mathrm{bA}$ & $97.2 \mathrm{~b}$ & $218.0 \mathrm{aA}$ & $188.0 \mathrm{aA}$ & $203.0 \mathrm{a}$ \\
\hline $26-1$ & $113.5 \mathrm{bA}$ & $93.5 \mathrm{bA}$ & $103.5 \mathrm{~b}$ & $234.0 \mathrm{aA}$ & $172.0 \mathrm{bB}$ & $203.0 \mathrm{a}$ \\
\hline BR106 & $128.0 \mathrm{aA}$ & $93.5 \mathrm{bB}$ & $110.7 \mathrm{a}$ & $222.5 \mathrm{aA}$ & $181.0 \mathrm{bB}$ & $201.7 \mathrm{a}$ \\
\hline $25-2$ & $109.0 \mathrm{bA}$ & $95.0 \mathrm{bA}$ & $102.0 \mathrm{~b}$ & $212.0 \mathrm{aA}$ & $182.0 \mathrm{bA}$ & $197.0 \mathrm{~b}$ \\
\hline $15-1$ & $117.0 \mathrm{bA}$ & $104.5 \mathrm{aA}$ & $110.7 \mathrm{a}$ & $206.0 \mathrm{bA}$ & $187.0 \mathrm{aA}$ & $196.5 \mathrm{~b}$ \\
\hline $25-1$ & $107.5 \mathrm{bA}$ & $93.0 \mathrm{bA}$ & $100.2 \mathrm{~b}$ & $205.0 \mathrm{bA}$ & $183.0 \mathrm{bA}$ & $194.0 \mathrm{~b}$ \\
\hline $28-5$ & $113.5 \mathrm{bA}$ & $96.5 \mathrm{bA}$ & $105.0 \mathrm{~b}$ & $207.5 \mathrm{bA}$ & $176.5 \mathrm{bB}$ & $192.0 \mathrm{~b}$ \\
\hline PO & $120.5 \mathrm{aA}$ & $102.0 \mathrm{aA}$ & $111.2 \mathrm{a}$ & $224.0 \mathrm{aA}$ & $159.0 \mathrm{bB}$ & $191.5 \mathrm{~b}$ \\
\hline $26-2$ & $107.5 \mathrm{bA}$ & $96.5 \mathrm{bA}$ & $102.0 \mathrm{~b}$ & $204.5 \mathrm{bA}$ & $177.0 \mathrm{bA}$ & $190.7 \mathrm{~b}$ \\
\hline $30-3$ & $113.0 \mathrm{bA}$ & $93.5 \mathrm{bA}$ & $103.2 \mathrm{~b}$ & $199.0 \mathrm{bA}$ & $177.5 \mathrm{bA}$ & $188.2 \mathrm{~b}$ \\
\hline $12-2$ & $124.0 \mathrm{aA}$ & $93.0 \mathrm{bB}$ & $108.5 \mathrm{a}$ & $198.5 \mathrm{bA}$ & $176.0 \mathrm{bB}$ & $187.2 \mathrm{~b}$ \\
\hline $1-5$ & $108.5 \mathrm{bA}$ & $92.5 \mathrm{bA}$ & $100.5 \mathrm{~b}$ & $199.0 \mathrm{bA}$ & $174.0 \mathrm{bA}$ & $186.5 \mathrm{~b}$ \\
\hline $32-3$ & $114.0 \mathrm{bA}$ & $83.5 \mathrm{bB}$ & $98.7 \mathrm{~b}$ & $208.0 \mathrm{bA}$ & $162.5 \mathrm{bB}$ & $185.2 \mathrm{~b}$ \\
\hline $2-5$ & $109.5 \mathrm{bA}$ & $92.5 \mathrm{bA}$ & $101.0 \mathrm{~b}$ & $194.0 \mathrm{bA}$ & $173.0 \mathrm{bA}$ & $183.5 \mathrm{~b}$ \\
\hline $12-3$ & $108.5 \mathrm{bA}$ & $88.5 \mathrm{bA}$ & $98.5 \mathrm{~b}$ & $197.5 \mathrm{bA}$ & $163.0 \mathrm{bB}$ & $180.2 \mathrm{~b}$ \\
\hline $10-6$ & $94.0 \mathrm{bA}$ & $80.0 \mathrm{bA}$ & $87.0 \mathrm{~b}$ & $198.5 \mathrm{bA}$ & $161.5 \mathrm{bB}$ & $180.0 \mathrm{~b}$ \\
\hline $15-3$ & $107.5 \mathrm{bA}$ & $84.0 \mathrm{bB}$ & $95.7 \mathrm{~b}$ & $200.0 \mathrm{bA}$ & $155.5 \mathrm{bB}$ & $177.7 \mathrm{~b}$ \\
\hline $35-5$ & $91.0 \mathrm{bA}$ & $75.5 \mathrm{bA}$ & $83.2 \mathrm{~b}$ & $169.5 \mathrm{bA}$ & $168.5 \mathrm{bA}$ & $169.0 \mathrm{~b}$ \\
\hline $11-3$ & $104.5 \mathrm{bA}$ & $80.5 \mathrm{bB}$ & $92.5 \mathrm{~b}$ & $180.5 \mathrm{bA}$ & $157.0 \mathrm{bA}$ & $168.7 \mathrm{~b}$ \\
\hline Means & $114.2 \mathrm{~A}$ & $95.2 \mathrm{~B}$ & 104.7 & $209.4 \mathrm{~A}$ & $179.3 \mathrm{~B}$ & 194.4 \\
\hline
\end{tabular}

Mean groups followed by same letter, Uppercase in rows and lowercase in columns in the same characteristic do not differ between themselves by Scott and Knott grouping test at 5\% significance level.

Source: Elaboration of the authors.

The average of the plant height in the high $\mathrm{N}$ environment was significantly superior to the average in low $\mathrm{N}$ environment, with 209.4 and $179.3 \mathrm{~cm}$ respectively (Table 2 ). In the average between environments nine populations composed the group of greater averages of the plant height, with averages ranging between 201.7 and 224.0 $\mathrm{cm}$. Noce et al. (2008) reported averages of the ear height of $117 \mathrm{~cm}$ for one single cross hybrid, values close to those obtained in this work, so it shows that populations from the group of greater plant height have potential to be explored as forage. Santos et al. (2002) claims that there is a correlation between the ear height and the grain yield, so, the selection or utilization of populations with larger values of the ear height may promote an increase in the plant height and the yield, and therefore being one characteristic of big interest in breeding process.

Von Pinho et al. (2007) evaluating maize cultivars for silage production, obtained $210 \mathrm{~cm}$ for the plant height in commercial maize cultivars, values close from those observed in populations from the group of greater averages. Mello, Nornberg and Rocha (2004) claims that greater plant height promotes an increase in the green mass yield, an important characteristic concerning cultivars directed to use in 
the silage production. Considering that this variable is correlated to green mass yield, the studied populations have forage production potential.

Nascimento, Tabosa and Tavares Filho (2003) and Santos et al. (2002) correlates the plant height with the ear height and the yield and they observed a high correlation between the plant height and the yield. On the other hand, excessively tall plants are more susceptible to lodging and stalk breaking and smaller plants in addition to the lower susceptibility to these problems; they have a better performance in a mechanized grain harvest. They also have a larger leaf/stalk ratio, however in the silage production the harvest is done before ripening, avoiding these problems of stalk breaking in tall plants.

The reduced plant height also makes possible higher sowing density, greater resistance to drought and reduction in leaf self-shading (PINTO et al., 2010; SEIFERT et al., 2006). Thus, tall maize genotypes may be better for utilization in the forage production, since they also have greater forage production than smaller plants.

The high $\mathrm{N}$ environment presented eight populations in the group of higher averages of yield of the plant green mass without the ear and seventeen populations in the group of smaller averages (Table 2). In the low $\mathrm{N}$ environments, populations did not present significant differences in this characteristic. Concerning environments of high and low $\mathrm{N}$, twelve populations did not present decreases in the yield of the plant green mass without ear when $\mathrm{N}$ stress was imposed.

Evaluating open-pollination populations Cruz et al. (2007), obtained an average of $15,742 \mathrm{~kg}$ $\mathrm{ha}^{-1}$ of plant green mass without ear. In this work, environments average betweend 32,374 and 17,098 $\mathrm{kg} \mathrm{ha}^{-1}$, these values are superior to those reported by Cruz et al. (2007) and close to those reported by Ramalho, Ramalho and Ribeiro (2001) who evaluated open-pollination populations utilizing half-sib families found $35030 \mathrm{~kg} \mathrm{ha}^{-1}$ of plant green mass without ear.

In high $\mathrm{N}$, the populations $1-5,12-4,26-1,12-6$ and 12-5 composed the group with greater averages of the ear green mass yield, with averages ranging from 20,336 to 22,880 $\mathrm{kg} \mathrm{ha}^{-1}$ (Table 3). Populations with smaller averages of ears green mass, presented values from 13,613 to $18,425 \mathrm{~kg} \mathrm{ha}^{-1}$. In low $\mathrm{N}$ environments, populations did not have significant differences in the ear green mass yield, even with averages varying from 9281 to $16747 \mathrm{~kg} \mathrm{ha}^{-1}$. The high $\mathrm{N}$ environment average was $17116 \mathrm{~kg} \mathrm{ha}^{-1}$ of the ear green mass, while in low $\mathrm{N}$ environment was $12570 \mathrm{~kg} \mathrm{ha}^{-1}$, being statistically inferior. In the environments average, populations 1-5, 12-4, 26$1,12-6$ and $12-5$ composed the group with greater averages of the ear green mass yield as well as in the high $\mathrm{N}$ environment.

Studying open-pollinated varieties Cruz et al. (2007) obtained averages of $9450 \mathrm{~kg} \mathrm{ha}^{-1}$ of the ear green mass. In this work, the average across environments had a variation from $18590 \mathrm{~kg} \mathrm{ha}^{-1}$ to $11797 \mathrm{~kg} \mathrm{ha}^{-1}$ which are significantly higher values when compared to those found by Cruz et al. (2007). Also Ramalho, Ramalho and Ribeiro (2001) evaluating open-pollination population found yields of $17530 \mathrm{~kg} \mathrm{ha}^{-1}$ green mass of ear, similar values to those found in this current work.

The ear participation in the plant mass did not present significant differences between populations in high and low N (Table 4). There wasn't any difference between high and low environments averages as well as in populations average. Only population 2-5 presented significant decrease in the ear participation in plant mass in the low $\mathrm{N}$ environment. 
Table 3. Average values of plant green mas without ear $\left(\mathrm{kg} \mathrm{ha}^{-1}\right)$ and ear green mass $\left(\mathrm{kg} \mathrm{ha}^{-1}\right)$ of 25 maize populations in High and Low N at Gurupi - TO, crop season 2009/2010.

\begin{tabular}{|c|c|c|c|c|c|c|}
\hline \multirow{2}{*}{ Population } & \multicolumn{3}{|c|}{ Plant green mass without ear } & \multicolumn{3}{|c|}{ Ear green mass } \\
\hline & High N & Low N & Mean & High N & Low N & Mean \\
\hline $12-6$ & $40067 \mathrm{aA}$ & $22908 \mathrm{aB}$ & $31487 \mathrm{a}$ & $20432 \mathrm{aA}$ & $16747 \mathrm{aA}$ & $18590 \mathrm{a}$ \\
\hline $26-1$ & 29796 bA & $21038 \mathrm{aA}$ & $25417 \mathrm{~b}$ & $20446 \mathrm{aA}$ & $16115 \mathrm{aA}$ & $18281 \mathrm{a}$ \\
\hline $1-5$ & $35599 \mathrm{aA}$ & $21120 \mathrm{aB}$ & $28359 \mathrm{a}$ & $22880 \mathrm{aA}$ & $13420 \mathrm{aB}$ & $18150 \mathrm{a}$ \\
\hline $12-4$ & $33220 \mathrm{aA}$ & $27761 \mathrm{aA}$ & $30490 \mathrm{a}$ & $21148 \mathrm{aA}$ & $14561 \mathrm{aB}$ & $17854 \mathrm{a}$ \\
\hline $12-5$ & $37139 \mathrm{aA}$ & $25671 \mathrm{aB}$ & $31405 \mathrm{a}$ & $20336 \mathrm{aA}$ & $13667 \mathrm{aB}$ & $17002 \mathrm{a}$ \\
\hline $25-5$ & $24929 \mathrm{bA}$ & $19566 \mathrm{aA}$ & $22247 \mathrm{~b}$ & $16940 \mathrm{bA}$ & $14520 \mathrm{aA}$ & $15730 \mathrm{~b}$ \\
\hline $30-3$ & 24846 bA & $18892 \mathrm{aA}$ & $21869 \mathrm{~b}$ & $18425 \mathrm{bA}$ & $12774 \mathrm{aB}$ & $15599 \mathrm{~b}$ \\
\hline $11-3$ & $25960 \mathrm{bA}$ & $14974 \mathrm{aB}$ & $20467 \mathrm{~b}$ & $17820 \mathrm{bA}$ & $12925 \mathrm{aB}$ & $15373 \mathrm{~b}$ \\
\hline $1-3$ & $38142 \mathrm{aA}$ & $26606 \mathrm{aB}$ & $32374 \mathrm{a}$ & $17710 \mathrm{bA}$ & $12939 \mathrm{aB}$ & $15324 \mathrm{~b}$ \\
\hline $25-2$ & $31762 \mathrm{aA}$ & $21835 \mathrm{aB}$ & $26799 \mathrm{a}$ & $17297 \mathrm{bA}$ & $13049 \mathrm{aA}$ & $15173 b$ \\
\hline $12-2$ & $31089 \mathrm{aA}$ & $19195 \mathrm{aB}$ & $25142 \mathrm{~b}$ & $16981 \mathrm{bA}$ & $12925 \mathrm{aA}$ & $14953 \mathrm{~b}$ \\
\hline $15-2$ & $32381 \mathrm{aA}$ & $24709 \mathrm{aA}$ & $28545 \mathrm{a}$ & $17944 \mathrm{bA}$ & $11921 \mathrm{aB}$ & 14932 b \\
\hline BR106 & $23237 \mathrm{bA}$ & $16981 \mathrm{aA}$ & $20109 \mathrm{~b}$ & $16252 \mathrm{bA}$ & $12609 \mathrm{aA}$ & $14430 \mathrm{~b}$ \\
\hline $12-3$ & $28174 \mathrm{bA}$ & $16830 \mathrm{aB}$ & $22502 \mathrm{~b}$ & $17545 \mathrm{bA}$ & $11000 \mathrm{aB}$ & $14273 \mathrm{~b}$ \\
\hline $32-3$ & $26758 \mathrm{bA}$ & $16459 \mathrm{aB}$ & $21608 \mathrm{~b}$ & $15661 \mathrm{bA}$ & $12279 \mathrm{aA}$ & $13970 \mathrm{~b}$ \\
\hline $25-1$ & 29508 bA & $21340 \mathrm{aA}$ & $25424 \mathrm{~b}$ & $15469 \mathrm{bA}$ & $12320 \mathrm{aA}$ & 13894 b \\
\hline $10-6$ & $27431 \mathrm{bA}$ & $17311 \mathrm{aB}$ & $22371 \mathrm{~b}$ & $14685 \mathrm{bA}$ & $12911 \mathrm{aA}$ & $13798 \mathrm{~b}$ \\
\hline $35-5$ & $25314 \mathrm{bA}$ & $16748 \mathrm{aA}$ & $21031 \mathrm{~b}$ & $15854 \mathrm{bA}$ & $11564 \mathrm{aA}$ & $13709 \mathrm{~b}$ \\
\hline $15-1$ & $24668 \mathrm{bA}$ & $18741 \mathrm{aA}$ & $21704 \mathrm{~b}$ & $15207 \mathrm{bA}$ & $11578 \mathrm{aA}$ & $13392 \mathrm{~b}$ \\
\hline $15-3$ & $24333 \mathrm{bA}$ & $17297 \mathrm{aA}$ & $20815 \mathrm{~b}$ & $15157 \mathrm{bA}$ & $11619 \mathrm{aA}$ & $13388 \mathrm{~b}$ \\
\hline $10-1$ & $27555 \mathrm{bA}$ & $17902 \mathrm{aB}$ & $22728 \mathrm{~b}$ & $13613 \mathrm{bA}$ & $13117 \mathrm{aA}$ & $13365 \mathrm{~b}$ \\
\hline $26-2$ & $28559 \mathrm{bA}$ & $15139 \mathrm{aB}$ & $21849 \mathrm{~b}$ & $16101 \mathrm{bA}$ & $10312 \mathrm{aB}$ & $13207 \mathrm{~b}$ \\
\hline PO & $26400 \mathrm{bA}$ & $18246 \mathrm{aA}$ & $22323 \mathrm{~b}$ & $15166 \mathrm{bA}$ & $10615 \mathrm{aA}$ & $12890 \mathrm{~b}$ \\
\hline $2-5$ & $18865 \mathrm{bA}$ & $15331 \mathrm{aA}$ & $17098 \mathrm{~b}$ & $14520 \mathrm{bA}$ & $9487 \mathrm{aB}$ & $12004 \mathrm{~b}$ \\
\hline $28-5$ & $28366 \mathrm{bA}$ & $17188 \mathrm{aB}$ & $22777 \mathrm{~b}$ & $14314 \mathrm{bA}$ & $9281 \mathrm{aB}$ & $11797 \mathrm{~b}$ \\
\hline Mean & $28964 \mathrm{~A}$ & $19591 \mathrm{~B}$ & 24277 & $17116 \mathrm{~A}$ & $12570 \mathrm{~B}$ & 14843 \\
\hline
\end{tabular}

Mean groups followed by same letter, Uppercase in rows and lowercase in columns in the same characteristic do not differ between themselves by Scott and Knott grouping test at 5\% significance level.

Source: Elaboration of the authors.

Mello, Nornberg and Rocha (2004) observed a larger ear contribution (63\%) than a leaf and stalk contribution (37\%) to plant mass, claiming that this ratio would be adequate for high quality silages. Guareschi et al. (2008) observed a variation from 22.1 to $39.5 \%$ of ear participation in plant green mass in one single cross hybrid while in this current work a variation from 34.1 to $43.4 \%$ in maize populations was found. In this work, an average of $38.5 \%$ of ear participation was observed, a value lower than those found in other papers. The larger ear ratio found in the literature may occur due to utilization of hybrids in these trials.
In the choice of a maize hybrid for silage production, it must have a high grain percentage and consequently, a higher percentage of ears in the plant total green mass, according to Melo et al. (1999), and this affirms that the observed variations in the percentage of ear in green mass is due to the genetic constitution of populations, emphasizing the importance of this study. Being the percentage of ear in green mass an important characteristic to silage quality (PINTO et al., 2010), it can be used as important parameter in populations with good values of plant green mass, in order to improve the silage quality produced from these populations. 
Characteristics such as high grain/green mass ratio, good fertilization management and cutting time leads to greater dry mass yield and greater grain yield, implying a nutritionally richer silage, more digestible and with lower fiber content, however if there is a high proportion of chaff and cob, these may reduce the effect of ear in the silage quality (MELO et al., 1999).

Table 4. Mean values of ear participation in plant green mass (\%) and total green mass $\left(\mathrm{kg} \mathrm{ha}^{-1}\right)$ of 25 maize populations in High and Low N at Gurupi-TO, crop season 2009/2010.

\begin{tabular}{|c|c|c|c|c|c|c|}
\hline \multirow{2}{*}{ Population } & \multicolumn{3}{|c|}{ Ear participation in plant green mass } & \multicolumn{3}{|c|}{ Total green mass } \\
\hline & High N & Low N & Mean & High N & Low N & Mean \\
\hline $12-6$ & $33.7 \mathrm{aA}$ & $42.2 \mathrm{aA}$ & $38.0 \mathrm{a}$ & $60500 \mathrm{aA}$ & $39655 \mathrm{aB}$ & $50077 \mathrm{a}$ \\
\hline $12-5$ & $35.4 \mathrm{aA}$ & $35.9 \mathrm{aA}$ & $35.6 \mathrm{a}$ & $57475 \mathrm{aA}$ & 39339 aA & 48407 a \\
\hline $12-4$ & $37.3 \mathrm{aA}$ & $36.7 \mathrm{aA}$ & $37.0 \mathrm{a}$ & 56416 aA & $40274 \mathrm{aB}$ & $48345 \mathrm{a}$ \\
\hline $1-3$ & $33.4 \mathrm{aA}$ & $32.8 \mathrm{aA}$ & $33.1 \mathrm{a}$ & $55564 \mathrm{aA}$ & $39834 \mathrm{aB}$ & $47699 \mathrm{a}$ \\
\hline $1-5$ & $39.0 \mathrm{aA}$ & $38.7 \mathrm{aA}$ & $38.9 \mathrm{a}$ & $58479 \mathrm{aA}$ & $34540 \mathrm{aB}$ & $46509 \mathrm{a}$ \\
\hline $26-1$ & $40.7 \mathrm{aA}$ & $43.5 \mathrm{aA}$ & $42.1 \mathrm{a}$ & $50242 \mathrm{aA}$ & $37152 \mathrm{aB}$ & 43697 a \\
\hline $15-2$ & $36.1 \mathrm{aA}$ & $32.2 \mathrm{aA}$ & $34.1 \mathrm{a}$ & $50009 \mathrm{aA}$ & $36946 \mathrm{aB}$ & $43477 \mathrm{a}$ \\
\hline $25-2$ & $35.2 \mathrm{aA}$ & $37.4 \mathrm{aA}$ & $36.3 \mathrm{a}$ & $49060 \mathrm{aA}$ & $34884 \mathrm{aB}$ & $41972 \mathrm{a}$ \\
\hline $12-2$ & $35.1 \mathrm{aA}$ & $40.5 \mathrm{aA}$ & $37.8 \mathrm{a}$ & $48070 \mathrm{aA}$ & $32120 \mathrm{aB}$ & $40095 \mathrm{~b}$ \\
\hline $25-1$ & $34.6 \mathrm{aA}$ & $36.6 \mathrm{aA}$ & $35.6 \mathrm{a}$ & $44976 \mathrm{bA}$ & $33660 \mathrm{aA}$ & $39318 \mathrm{~b}$ \\
\hline $25-5$ & $41.1 \mathrm{aA}$ & $42.6 \mathrm{aA}$ & $41.8 \mathrm{a}$ & $41869 \mathrm{bA}$ & $34086 \mathrm{aA}$ & $37977 \mathrm{~b}$ \\
\hline $30-3$ & $42.4 \mathrm{aA}$ & $40.2 \mathrm{aA}$ & $41.3 \mathrm{a}$ & $43271 \mathrm{bA}$ & $31666 \mathrm{aA}$ & $37469 \mathrm{~b}$ \\
\hline $12-3$ & $38.3 \mathrm{aA}$ & $39.3 \mathrm{aA}$ & $38.8 \mathrm{a}$ & $45719 \mathrm{bA}$ & $27830 \mathrm{aB}$ & $36774 \mathrm{~b}$ \\
\hline $10-6$ & $34.6 \mathrm{aA}$ & $42.9 \mathrm{aA}$ & $38.8 \mathrm{a}$ & $42116 \mathrm{bA}$ & $30223 \mathrm{aA}$ & $36169 \mathrm{~b}$ \\
\hline $10-1$ & $33.0 \mathrm{aA}$ & $42.2 \mathrm{aA}$ & $37.6 \mathrm{a}$ & $41154 \mathrm{bA}$ & $31034 \mathrm{aA}$ & $36094 \mathrm{~b}$ \\
\hline $11-3$ & $40.6 \mathrm{aA}$ & $46.3 \mathrm{aA}$ & $43.4 \mathrm{a}$ & $43780 \mathrm{bA}$ & $27899 \mathrm{aB}$ & $35839 \mathrm{~b}$ \\
\hline $32-3$ & $37.0 \mathrm{aA}$ & $42.8 \mathrm{aA}$ & $39.9 \mathrm{a}$ & $42419 \mathrm{bA}$ & $28737 \mathrm{aB}$ & $35578 \mathrm{~b}$ \\
\hline P.O. & $36.5 \mathrm{aA}$ & $36.8 \mathrm{aA}$ & $36.6 \mathrm{a}$ & $41566 \mathrm{bA}$ & $28861 \mathrm{aA}$ & $35214 \mathrm{~b}$ \\
\hline $15-1$ & $37.9 \mathrm{aA}$ & $38.3 \mathrm{aA}$ & $38.1 \mathrm{a}$ & $39875 \mathrm{bA}$ & $30319 \mathrm{aA}$ & $35097 \mathrm{~b}$ \\
\hline $26-2$ & $37.3 \mathrm{aA}$ & $40.6 \mathrm{aA}$ & $39.0 \mathrm{a}$ & $44660 \mathrm{bA}$ & $25451 \mathrm{aB}$ & $35055 \mathrm{~b}$ \\
\hline $35-5$ & $38.6 \mathrm{aA}$ & $42.1 \mathrm{aA}$ & $40.3 \mathrm{a}$ & $41896 \mathrm{bA}$ & $27582 \mathrm{aB}$ & $34739 \mathrm{~b}$ \\
\hline $28-5$ & $33.5 \mathrm{aA}$ & $35.1 \mathrm{aA}$ & $34.3 \mathrm{a}$ & $42680 \mathrm{bA}$ & $26469 \mathrm{aB}$ & $34574 \mathrm{~b}$ \\
\hline BR106 & $46.2 \mathrm{aA}$ & $40.1 \mathrm{aA}$ & $43.1 \mathrm{a}$ & $35722 \mathrm{bA}$ & $33357 \mathrm{aA}$ & $34540 \mathrm{~b}$ \\
\hline $15-3$ & $38.4 \mathrm{aA}$ & $40.2 \mathrm{aA}$ & $39.3 \mathrm{a}$ & $39490 \mathrm{bA}$ & $28916 \mathrm{aA}$ & $34203 \mathrm{~b}$ \\
\hline $2-5$ & $46.9 \mathrm{aA}$ & $35.8 \mathrm{aB}$ & $41.3 \mathrm{a}$ & $31666 \mathrm{bA}$ & $26538 \mathrm{aA}$ & $29102 \mathrm{~b}$ \\
\hline Mean & $39.3 \mathrm{~A}$ & $37.8 \mathrm{~A}$ & 38.5 & $45947 \quad \mathrm{~A}$ & $32295 \mathrm{~A}$ & 39121 \\
\hline
\end{tabular}

Mean groups followed by same letter, Uppercase in rows and lowercase in columns in the same characteristic do not differ between themselves by Scott and Knott grouping test at 5\% significance level.

Source: Elaboration of the authors.

In total green mass, populations $12-6,1-5,12-$ $5,12-4,1-3,26-1,15-2,25-2$ and 12-2 presented greater averages in high $\mathrm{N}$ environment, with averages from 48070 to $60500 \mathrm{~kg} \mathrm{ha}^{-1}$. Populations in the group of smaller averages of total green mass presented averages between 31666 and 45719 $\mathrm{kg} \mathrm{ha}^{-1}$ (Table 4). Also in low N, populations did not differ in total green mass, even with averages ranging from 25,451 to $40,274 \mathrm{~kg} \mathrm{ha}^{-1}$, which can be justified by smaller expression of genetic variability in limiting environments such as under nitrogen stress. This effect can be observed not only in total green mass but also in plant green mass without ear and ear green mass.

There was variation between environments of high $\mathrm{N}$ and low $\mathrm{N}$ from 45,947 to $32,295 \mathrm{~kg} \mathrm{ha}^{-1}$ 
of total green mass, being a significant difference. A reduction is expected in biomass production in nitrogen stressing environments since nitrogen is a component of proteins, enzymes, coenzymes, nucleic acids, phytochrome, chlorophyll and besides, it affects rates of leaf initiation and expansion and also leaves final size, senescence intensity, foliar area index and consequently biomass production (GAVA et al., 2010).

Guareschi et al. (2008) evaluating one single cross hybrid maize with the same stand and spacing of this current work, obtained an inferior yield to that found in this work, however these authors observed that keeping the same plant population and reducing spacing is possible to increase maize biomass yield considerably without increasing costs with the acquisition of hybrid seeds.

Ramalho, Ramalho and Ribeiro (2001) evaluating open pollinated populations utilizing half-sib families achieved a yield of $52560 \mathrm{~kg} \mathrm{ha}^{-1}$ of plant total green mass. Chaves et al. (2008) affirms that in many breeding programs, genotypes with high grain and green mass yield has been recommended for silage production, so the utilization of genotypes of higher green mass yield to obtain new cultivars will consequently obtain cultivars possibility with high grain yield.

Médici et al. (2004) affirms that the selection of high performance cultivars under low $\mathrm{N}$ conditions in maize germplasm seems to improve the $\mathrm{N}$ use efficiency to produce grains and biomass in either environments, high and low nitrogen availability. Genotypes considered efficient in nitrogen use show larger foliar area index than non-efficient genotypes, improving also the efficiency in canopy light interception, use of water and nutrients and consequently resulting in a better soil coverage and increasing maize biomass yield.
In averages of high and low $\mathrm{N}$ environments, populations 12-6, 1-5, 12-5, 12-4, 1-3, 26-1, 15-2 and 25-2 presented greater averages, varying from 50077 to $41972 \mathrm{~kg} \mathrm{ha}{ }^{-1}$. Thus these populations can be utilized in development of genotypes aiming the production of forage, silage and soil coverage. Evaluating ten commercial hybrids and their combinations in a diallel, Chaves et al. (2008) found values ranging from 29900 to $49900 \mathrm{~kg} \mathrm{ha}^{-1}$ for plant total green mass, similar values to those found in this current study, however is noticeable that even with similar values, this current study evaluates open pollination populations, that doesn't exploit heterosis as Chaves et al. (2008) did in his evaluated genotypes.

Thus, populations 12-6, 1-5, 12-5, 12-4, 1-3, 26-1, 15-2 and 25-2 can be utilized to produce commercial genotypes not only to low $\mathrm{N}$ availability but also to high availability conditions, being suited to farmers with higher investments in commercial maize production.

The nitrogen use efficiency by Moll, Kamprath and Jackson (1982) methodology showed average of 264.1 which indicates that for every $\mathrm{kg}$ of $\mathrm{N}$ applied in soil, the plant produces $264.1 \mathrm{~kg}$ of green mass (Table 5). Comparing populations in high and low $\mathrm{N}$, it can be observed that all populations in low $\mathrm{N}$ environment presented themselves statically superior, highlighting that to improve nitrogen use efficiency the nitrogen fertilization should be reduced to levels that still guarantee satisfactory yields (MAJEROWICZ et al., 2002; MÉDICI et al., 2004). Corroborating with this study, Fernandes, Buzetti e Andrade (2005) and Cancellier et al. (2011) report the same effect concerning grain yield in evaluations of commercial hybrids and maize populations respectively. 
Table 5. Mean values of nitrogen use efficiency in total green mass production according to Moll, Kamprath and Jackson (1982) and Fischer, Johnson and Edmeades (1983) in 25 maize populations in High and Low N at Gurupi-TO, crop season 2009/2010.

\begin{tabular}{|c|c|c|c|c|c|}
\hline \multirow{2}{*}{ Population } & \multicolumn{3}{|c|}{ Moll } & \multicolumn{2}{|c|}{ Fischer } \\
\hline & High N & Low $\mathrm{N}$ & Mean & Index & $\%$ \\
\hline $26-2$ & $256.5 \mathrm{aB}$ & $1060.0 \mathrm{bA}$ & $658.2 \mathrm{~b}$ & $1.252 \mathrm{a}$ & 122.3 \\
\hline $12-5$ & $330.0 \mathrm{aB}$ & $1639.0 \mathrm{aA}$ & $984.5 \mathrm{a}$ & $1.215 \mathrm{a}$ & 118.7 \\
\hline $1-5$ & $336.0 \mathrm{aB}$ & $1439.0 \mathrm{aA}$ & $887.5 \mathrm{a}$ & $1.194 \mathrm{a}$ & 116.6 \\
\hline $12-3$ & $263.0 \mathrm{aB}$ & $1160.0 \mathrm{bA}$ & $711.5 \mathrm{~b}$ & $1.163 \mathrm{a}$ & 113.6 \\
\hline $28-5$ & $245.0 \mathrm{aB}$ & $1103.0 \mathrm{bA}$ & $674.0 \mathrm{~b}$ & $1.133 \mathrm{a}$ & 110.7 \\
\hline $11-3$ & $251.5 \mathrm{aB}$ & $1162.5 \mathrm{bA}$ & $707.0 \mathrm{~b}$ & $1.105 \mathrm{a}$ & 107.9 \\
\hline $12-6$ & $348.0 \mathrm{aB}$ & $1652.5 \mathrm{aA}$ & $1000.2 \mathrm{a}$ & $1.072 \mathrm{a}$ & 104.7 \\
\hline $35-5$ & $240.5 \mathrm{aB}$ & $1149.0 \mathrm{bA}$ & $694.7 \mathrm{~b}$ & $1.058 \mathrm{a}$ & 103.3 \\
\hline $12-2$ & $276.0 \mathrm{aB}$ & $1338.0 \mathrm{bA}$ & $807.0 \mathrm{~b}$ & $1.057 \mathrm{a}$ & 103.2 \\
\hline $32-3$ & $244.0 \mathrm{aB}$ & $1197.5 \mathrm{bA}$ & $720.7 \mathrm{~b}$ & $1.035 \mathrm{a}$ & 101.1 \\
\hline $1-3$ & $319.5 \mathrm{aB}$ & $1659.5 \mathrm{aA}$ & $989.5 \mathrm{a}$ & $1.026 \mathrm{a}$ & 100.2 \\
\hline P.O. & $239.0 \mathrm{aB}$ & $1202.5 \mathrm{bA}$ & $720.7 \mathrm{~b}$ & $1.013 \mathrm{a}$ & 98.9 \\
\hline $12-4$ & $324.0 \mathrm{aB}$ & $1678.0 \mathrm{aA}$ & $1001.0 \mathrm{a}$ & $1.009 \mathrm{a}$ & 98.6 \\
\hline $25-2$ & $282.0 \mathrm{aB}$ & $1453.5 \mathrm{aA}$ & $867.7 \mathrm{a}$ & $0.989 a$ & 96.6 \\
\hline $10-6$ & $242.0 \mathrm{aB}$ & $1259.5 \mathrm{bA}$ & $750.7 \mathrm{~b}$ & $0.987 \mathrm{a}$ & 96.4 \\
\hline $15-3$ & $227.0 \mathrm{aB}$ & $1205.0 \mathrm{bA}$ & $716.0 \mathrm{~b}$ & $0.971 \mathrm{a}$ & 94.8 \\
\hline $26-1$ & $289.0 \mathrm{aB}$ & $1548.0 \mathrm{aA}$ & $918.5 \mathrm{a}$ & $0.960 \mathrm{a}$ & 93.8 \\
\hline $30-3$ & $248.5 \mathrm{aB}$ & $1319.5 \mathrm{bA}$ & $784.0 \mathrm{~b}$ & $0.959 \mathrm{a}$ & 93.7 \\
\hline $15-2$ & $287.5 \mathrm{aB}$ & $1539.0 \mathrm{aA}$ & $913.2 \mathrm{a}$ & $0.950 \mathrm{a}$ & 92.8 \\
\hline BR106 & $205.5 \mathrm{aB}$ & $1389.5 \mathrm{aA}$ & $797.5 \mathrm{~b}$ & $0.944 \mathrm{a}$ & 92.2 \\
\hline $25-1$ & $258.5 \mathrm{aB}$ & $1402.5 \mathrm{aA}$ & $830.5 \mathrm{~b}$ & $0.941 \mathrm{a}$ & 91.9 \\
\hline $10-1$ & $236.5 \mathrm{aB}$ & $1293.0 \mathrm{bA}$ & $764.7 \mathrm{~b}$ & $0.936 \mathrm{a}$ & 91.4 \\
\hline $15-1$ & $229.0 \mathrm{aB}$ & $1263.5 \mathrm{bA}$ & $746.2 \mathrm{~b}$ & $0.932 \mathrm{a}$ & 91.0 \\
\hline $25-5$ & $241.0 \mathrm{aB}$ & $1420.0 \mathrm{aA}$ & $830.5 \mathrm{~b}$ & $0.858 \mathrm{a}$ & 83.8 \\
\hline $2-5$ & $182.0 \mathrm{aB}$ & $1105.5 \mathrm{bA}$ & $643.7 \mathrm{~b}$ & $0.835 \mathrm{a}$ & 81.6 \\
\hline Mean & $264.1 \mathrm{~B}$ & $1345.5 \mathrm{~A}$ & 804.7 & 1.020 & 100.0 \\
\hline
\end{tabular}

Mean groups followed by same letter, Uppercase in rows and lowercase in columns do not differ between themselves by Scott and Knott grouping test at 5\% significance level.

Source: Elaboration of the authors.

Gava et al. (2010) reports this same effect evaluating aboveground dry matter. These authors quote that such response occurs due to a larger supply of readily available nitrogen to the plant, provided by higher doses of fertilizer. However, due to this greater availability losses may also occur through processes of volatilization, leaching and denitrification, which results in smaller nitrogen use efficiency.

In the low $\mathrm{N}$ environment, two groups of average were formed, with eleven populations in the group of greater indexes, showing that these populations are considered more efficient in nitrogen use according to the method of Moll, Kamprath and Jackson (1982). Concerning averages of across the low and high $\mathrm{N}$ environments, two groups were observed, with eight populations in the group of greater averages, being considered the most efficient in $\mathrm{N}$ use, 12-4, 1-3, 12-6, 12-5, 26-1, 15-2, 25-2 and $1-5$, presenting indexes from 1001.0 to 867.7 . It is important to notice that the treatment control (BR $106)$ is found in the group of smaller averages, so it is considered inefficient. Corroborating to this current work, Fernandes, Buzetti e Andrade (2005) also reported that the cultivar BR 106 is inefficient in $\mathrm{N}$ use. 
McCullough et al. (1994), studying genotypes contrasting in NUE, observed that the most sensible genotype for $\mathrm{N}$ deficiency was the one which presented the greater difference between levels of N. Such effects can be observed through the index obtained from the method of Fischer, Johnson and Edmeades (1983), since the index calculation takes into account the difference between the high and low $\mathrm{N}$ environment, where in small indexes are populations with small response to reductions in supplied nitrogen.

According to the method of $\mathrm{N}$ use efficiency proposed by Fischer, Johnson and Edmeades (1983) used in forage production, it was not possible to identify efficient populations, nevertheless population 26-2 presented itself 22,3\% more efficient than the average of this index (Table 5). Cancellier et al. (2011) did not observe differences between populations concerning grain yield utilizing the method of Fischer, Johnson and Edmeades (1983).

Populations 12-6, 1-3, 12-5 and 1-5 were above average by the index of Fischer, Johnson and Edmeades (1983) without differing from other populations in this index and they were statically superior in the index of Moll, Kamprath and Jackson (1982), being considered efficient in use of available nitrogen in soil to forage yield. In conclusion, the populations 12-4, 1-3, 12-6, 12-5, 26-1, 15-2, 25-2 and $1-5$ could be considered efficient in $\mathrm{N}$ use. The populations 12-6, 12-5, 12-4, 1-3, 1-4, 1-5 and 15-2 are the best populations to use in high and low $\mathrm{N}$ environment, combining great production of green mass and being efficient in $\mathrm{N}$ use.

\section{Acknowledgments}

The authors acknowledge Conselho Nacional de Desenvolvimento Científico e Tecnológico (CNPq) and Coordenação de Aperfeiçoamento de Pessoal de Nível Superior (CAPES) for financial support and providing scholarship to the authors.

\section{References}

CANCELLIER, L. L.; AFFÉRRI, F. S.; CARVALHO, E. V.; DOTTO, M. A.; LEÃO, F. F. Eficiência no uso de nitrogênio e correlação fenotípica em populações tropicais de milho no Tocantins. Revista Ciência Agronômica, Fortaleza, v. 42, n. 1, p. 139-148, 2011.

CARVALHO, H. W. L.; SOUZA, E. M. Ciclos de seleção de progênies de meios-irmãos do milho BR 5011 Sertanejo. Pesquisa Agropecuária Brasileira, Brasília, v. 42, n. 6, p. 803-809, 2007.

CHAVES, L. G.; MIRANDA, G. V.; SOUZA, L. V.; GOMES, O. P.; OLIVEIRA, J. S. Parental commercial maize selection for silage production. Revista Brasileira de Milho e Sorgo, Sete Lagoas, v. 7, n. 2, p. 183-194, 2008.

COIMBRA, R. R.; MIRANDA, G. V.; CRUZ, C. D.; MELO, A. V.; ECKERT, F. R. Caracterização e divergência genética de populações de milho resgatadas do Sudeste de Minas Gerais. Revista Ciência Agronômica, Fortaleza, v. 41, n. 1, p. 159-166, 2010.

CRUZ, J. C.; PEREIRA FILHO, I. A.; PEREIRA, F. T. F.; ALVARENGA, R. C.; KONZEN, E. A. Produção orgânica de grãos e silagem de milho. Revista Brasileira de Agroecologia, Cruz Alta, v. 2, n. 1, p. 1186-1189, 2007.

FAGERIA, N. K.; SANTOS, A. B.; CUTRIM, V. A. Produtividade de arroz irrigado e eficiência de uso do nitrogênio influenciadas pela fertilização nitrogenada. Pesquisa Agropecuária Brasileira, Brasília, v. 42, n. 7, p. 1029-1034, 2007.

FERNANDES, F. C. S.; BUZETTI, S.; A. R. F. O.; ANDRADE, J. A. C. Doses, eficiência e uso de nitrogênio por seis cultivares de milho. Revista Brasileira de Milho e Sorgo, Sete Lagoas, v. 4, n. 2, p. 195-204, 2005.

FISCHER, K. S.; JOHNSON, E. C.; EDMEADES, G. $\mathrm{O}$. Breeding and selection for drought in tropical maize. México: CIMMYT, 1983. 19 p.

GAVA, G. J. C.; OLIVEIRA, M. W.; SILVA, M. A.; JERONIMO, E. M.; CRUZ, J. C. S.; TRIVELIN, P. C. O. Produção de fitomassa e acúmulo de nitrogênio em milho cultivado com diferentes doses de ${ }^{15} \mathrm{~N}$-uréia. Semina: Ciências Agrárias, Londrina, v. 31, n. 4, p. 851862, 2010.

GUARESCHI, R. F.; GAZOLLA, P. R.; PERIN, A.; ROCHA, A. C. Produção de massa de milho silagem em função do arranjo populacional e adubação. Revista Ciência Agronômica, Fortaleza, v. 39, n. 3, p. 468-475, 2008. 
JAKELAITIS, A.; SILVA, A. A.; FERREIRA, L. R. Efeitos do nitrogênio sobre o milho cultivado em consórcio com Brachiaria brizantha. Acta Scientiarum Agronomy, Maringá, v. 27, n. 1, p. 39-46, 2005.

MAJEROWICZ, N.; PEREIRA, J. M. S.; MEDICI, L. O.; BISON, O.; PEREIRA, M. B.; SANTOS JÚNIOR, U. M. Estudo da eficiência de uso do nitrogênio em variedades locais e melhoradas de milho. Revista Brasileira de Botânica, São Paulo, v. 25, n. 2, p. 129-136, 2002.

McCULLOUGH, D. E.; IRARDIN, P. H.; MIHAJLOVIC, M.; AGUILERA, A.; TOLLENAAR, M. Infuence of N supply on development and dry matter accumulation of old and a new maize hibrid. Canadian Journal of Plant Science, Ottawa, v. 74, n. 3, p. 471-474, 1994.

MÉDICI, L. O.; PEREIRA, M. B.; LEA, P. J.;AZEVEDO, R. A. Diallel analysis of maize lines with contrasting responses to applied nitrogen. Journal of Agricultural Science, Toronto, v. 142, n. 5, p. 535-541, 2004.

MELLO, R.; NORNBERG, J. L.; ROCHA, M. G. Potencial produtivo e qualitativo de híbridos de milho, sorgo e girassol para ensilagem. Revista Brasileira de Agrociência, Pelotas, v. 10, n. 1 p. 87-95, 2004.

MELO, W. M. C.; VON PINHO, R. G.; CARVALHO, M. L. M.; VON PINHO, E. V. R. Avaliação de cultivares de milho para produção de silagem na região de LavrasMG. Ciência e Agrotecnologia, Lavras, v. 23, n. 1, p. 3139, 1999.

MOLL, R. H.; KAMPRATH, E. J.; JACKSON, W. A. Analysis and interpretation of factors which contribute to efficiency of nitrogen utilization. Agronomy Journal, Madison, v. 74, n. 3, p. 562-564, 1982.

MONNEVEUX, P.; ZAID, P. H.; SANCHES, C. Population Density and Low Nitrogen affects yield - Associated traits in tropical Maize. Crop Science, Madison, v. 45, n. 2, p. 535-545, 2005.

NASCIMENTO, M. M. A.; TABOSA, J. N.; TAVARES FILHO, J. J. Avaliação de cultivares de milho no agreste semi-árido de Pernambuco. Revista Brasileira de Engenharia Agrícola e Ambiental, Campina Grande, v. 7, n. 1, p. 53-56, 2003.

NOCE, M. A.; SOUZA, I. F.; KARAM, D.; FRANÇA, A. C.; MACIEL, G. M. Influência da palhada de gramíneas forrageiras sobre o desenvolvimento da planta de milho e das plantas daninhas. Revista Brasileira de Milho e Sorgo, Sete Lagoas, v. 7, n. 3, p. 265-278, 2008.

PINTO, A. P.; LANÇANOVA, J. C.; LUGÃO, S. M. B.; ROQUE, A. P.; ABRAHÃO, J. J. S.; OLIVEIRA, J. S.; LEME, M. C. J.; MIZUBUTI, I. Y. Avaliação de doze cultivares de milho (Zea mays L.) para silagem. Semina: Ciências Agrárias, Londrina, v. 31, n. 4, p. 1071-1078, 2010.

PISSINATI, A.; OLIVEIRA, M. A.; PISSINATI, A.; MOREIRA, A. Management and cost of urea application in maize grown in northern Paraná state, Brazil. Revista de Ciências Agrárias, Belém, v. 56, n. 3, p. 235-241, 2013.

PRESTERL, T.; GROH, S.; LANDBECK, M.; SEITZ, G.; SCHMIDT, W.; GEIGER, H. H. Nitrogen uptake and utilization efficiency of European maize hybrids developed under conditions of low and high nitrogen. Plant Breeding, Malden, v. 121, n. 6, p. 480-486, 2002.

RAMALHO, A. R.; RAMALHO, M. A. P.; RIBEIRO, P. H. E. Comportamento de famílias de meios-irmãos em diferentes épocas de semeadura visando à produção de forragem de milho. Ciência e Agrotecnologia, Lavras, v. 25 , n. 3, p. $510-518,2001$.

ROESCH, L. F.; CAMARGO, F.; SELBACH, P.; SÁ, E. S.; PASSAGLIA, L. Identificação de cultivares de milho eficientes na absorção de nitrogênio e na associação com bactérias diazotróficas. Ciência Rural, Santa Maria, v. 35 , n. 4, p. 924-927, 2005.

SANTOS，P. G.; JULIATTI， F. C.; BUIATTI， A. L.; HAMAWAKI, O. T. Avaliação do desempenho agronômico de híbridos de milho em Uberlândia, MG. Pesquisa Agropecuária Brasileira, Brasília, v. 37, n. 5, p. 597-602, 2002.

SEIFERT, A. L.; CARPENTIERI-PIPOLO, V.; FERREIRA, J. M.; GERAGE, A. C. Análise combinatória de populações de milho pipoca em Top Crosses. Pesquisa Agropecuária Brasileira, Brasília, v. 41, n. 5, p. 771-778, 2006.

SOARES, M. O.; MIRANDA, G. V.; GUIMARÃES, L. J. M.; MARRIEL, I. E.; GUIMARÃES, C. T. Parâmetros genéticos de uma população de milho em níveis contrastantes de nitrogênio. Revista Ciência Agronômica, Fortaleza, v. 42, n. 1, p. 168-174, 2011.

SOUZA, L. V.; MIRANDA, G. V.; GALVÃO, J. C. C.; ECKERT, F. R.; MANTOVANI, E. E.; LIMA, R. O.; GUIMARÃES, L. J. M. Genetic control of grain yield and nitrogen use efficiency in tropical maize. Pesquisa Agropecuária Brasileira, Brasília, v. 43, n. 11, p. 1517$1523,2008$.

VON PINHO, R. G.; VASCONCELOS, R. C.; BORGES, I. D.; RESEDE, A. V. Produtividade e qualidade da silagem de milho e sorgo em função da época de semeadura. Bragantia, Campinas, v. 66, n. 2, p. 235-245, 2007. 